\title{
Variation and Correlations Among Stem Growth and Wood Traits of Calycophyllum spruceanum Benth. from the Peruvian Amazon
}

\author{
By J. C. Weber ${ }^{1)}$ and C. Sotelo Montes ${ }^{2)}$ \\ World Agroforestry Centre (ICRAF), Apartado Postal 1558, Lima, Peru
}

(Received 15 ${ }^{\text {th }}$ April 2005)

\begin{abstract}
Calycophyllum spruceanum Benth. is an important tree for timber and energy in the western Amazon, with expanding national and international markets for its wood. There is relatively little information, however, about geographic variation in tree growth and wood properties, and correlations among these traits. The first provenance trial was established with farming communities in the Peruvian Amazon. Seven provenances, sampled from regions near the equator, were tested in three planting zones located in one watershed. Variation and correlations were investigated in stem growth at 30 and 42 months, wood density (in the lower and upper parts of the stem) and mean heat content of stem wood at 32 months. Stem height varied significantly among provenances and planting zones, but zones accounted for much more variation than provenances. Stem wood traits did not vary significantly among provenances. Wood density was greater in the lower than in the upper stem. Wood density in the upper stem and the difference in density between the lower and upper stem varied significantly among planting zones: density in the upper stem was lowest, and the difference in density between the lower and upper stem was largest in the zone where trees grew most rapidly. Phenotypic correlations between stem growth and wood density differed in sign among planting zones, suggesting that selecting fastgrowing trees could indirectly reduce wood density in environments where trees grow slowly, and increase the difference in wood density between the lower and upper stem in environments where trees grow very rapidly. Correlations between stem growth and wood heat content were stable across zones, and indicated that larger trees tended to have wood with higher heat content. Stem-wood heat content varied with provenance latitude/longitude in the sample region, but none of the other traits varied clinally. Results indicate that there is potential to select faster-growing provenances at an early age, but this could affect wood density in certain environments.
\end{abstract}

Key words: provenance, environment, height, diameter, wood density \& heat content.

\section{Introduction}

The Amazon Basin is extremely rich in tree species (LAURANCE, 2001), but the extent and distribution of genetic variation in these species is not well known.

\footnotetext{
1) Current address: 2224 NW 11 $1^{\text {th }}$ Street, Corvallis, Oregon, 97330, USA. Email: johncrweber@aol.com

2) Current address: Département des Sciences du Bois et de la Forêt, Pavillon Abitibi-Price, Université Laval, Québec, G1K-7P4, Canada.

Email: alcira-del-carmen.sotelo-montes.1@ulaval.ca
}

Farmers in the Peruvian Amazon use more than 150 indigenous tree species, and rank Calycophyllum spruceanum Benth. (Rubiaceae family) as one of the best suited for the production of lumber, poles, firewood and charcoal in agroforestry systems (SOTELO MONTES and WEBER, 1997). Revenue from the sale of these products can contribute significantly to farmers' income (LABARtA and Weber, 1998; Pinedo-VAsquez et al., 2001). The dense, tan-coloured wood is used for furniture, wall paneling and floors, and its national and international markets are expanding (TOLEDO and RINCÓN, 1996). It is known in the markets as Capirona (Peru), Palo blanco (Argentina), Guayabochi (Bolivia), Pau mulato (Brazil), Alazano (Colombia), Corusicao (Ecuador), Araguato (Venezuela), Palo camarón (Spain), Citronnier bresilien (France) and Brasil Zitrohenholz (Germany).

Calycophyllum spruceanum is a pioneer species that colonizes the floodplain and disturbed forests below 650 $\mathrm{m}$ elevation in the western Amazon of Peru, Brazil, Ecuador and Colombia (LINARES et al., 1992). Trees mature in 2-3 years in open-grown conditions, and the small, winged seeds are dispersed by wind and water. The canopy is not dense, and partial leaf abscission may occur during the dry season. Trees can attain heights of $35 \mathrm{~m}$ with stem diameters of $1.8 \mathrm{~m}$ at breast height (SEARs, 2003). The wood is diffuse porous and very dense when mature $\left(0.76 \mathrm{~g} / \mathrm{cm}^{3}\right.$ according to ACEVEDO and KIKATA, $1994 ; 0.645 \mathrm{~g} / \mathrm{cm}^{3}$ according to WoODCOCK, 2000). Farmers value the species because it grows rapidly, the wood is dense and relatively uniform, and the wood has a high heat content, making it suitable for firewood and charcoal (Sotelo Montes and WeBER, 1997; SEARS, 2003). Stems can be harvested for construction poles and charcoal/firewood after 2 to 3 years, or sawn timber after 15 to 20 years, and then coppiced for successive harvests. In addition, farmers regularly cut branches beginning in the second year for firewood and charcoal production.

The first provenance trial of Calycophyllum spruceanum was established with farming communities in the Peruvian Amazon. This was the first provenance trial of any indigenous tree species in the Peruvian Amazon. Results from this trial at 18 months demonstrated that there is potential to select fast-growing provenances with desirable branch-wood properties (high density and heat content) for firewood and charcoal production (Sotelo Montes et al., 2003). At 18 months there was (a) a significant difference in stem growth among provenances, although this accounted for 
relatively little variation compared with planting zones, (b) a weak, positive phenotypic correlation between stem growth and branch-wood density, and between branchwood density and heat content, and (c) a latitudinal cline in branch-wood heat content. The positive correlation between growth and branch-wood density suggests that it may be possible to select fast-growing provenances without reducing branch-wood density, assuming that the genetic correlation is also positive (ZOBEL and JETT, 1995). However, the correlation differed in sign among planting zones in the trial, suggesting that selection of fast-growing trees in certain environments may indirectly reduce branch-wood density.

In this paper, we present additional results from the same provenance trial. The objectives are to assess the relative magnitude of variation in stem height, diameter, wood density and heat content due to provenances and planting zones; and evaluate the phenotypic correlations among these traits in three different planting zones. Trees were evaluated at 30 and 42 months for stem height and diameter, and at 32 months for stemwood density and heat content. Since wood density often varies within the stem and may reduce the tree's timber value (ZOBEL and VAN BUIJTENEN, 1989), variation in wood density was evaluated near the base of the stem and just below the live crown. The major results are compared with other tropical hardwood species, and some practical implications are discussed.

\section{Materials and Methods}

\section{Sample region, study area and experimental design}

Eleven natural populations were sampled in the Peruvian Amazon (Figure 1). Seeds were collected from 35 trees in each population in 1996. Trees were randomly selected from those that had sufficient fruits, no external disease symptoms, and were at least $100 \mathrm{~m}$ from any other tree marked for collection. Latitude and longitude of each sampled tree were recorded using a Global Positioning System (elevation estimates were not always reliable).

Accurate climatic data are not available for the locations of the populations. In general, mean annual rainfall increases from south to north and from west to east (range approximately 1400 to $3200 \mathrm{~mm}$ ) across the sample region, and mean annual temperature increases from south to north (range approximately 24 to $28^{\circ} \mathrm{C}$ ) (KALLIOLA et al., 1993). Elevation ranges from approximately 180 to $240 \mathrm{~m}$ above sea level in the southern part of the sample region, and from 150 to $180 \mathrm{~m}$ above sea level in the northern part.

A single seedlot was created from each provenance by mixing an equal volume of seed from each of the 35 trees. Seedlings were grown in nursery bags for 1 year. Fungal pathogens caused high mortality in the nursery, especially in four provenances (Atalaya, Tiruntán, Shukushuyacu, Von Humboldt). In addition, seed viability decreased more rapidly than expected, making it impossible to resow several provenances in the nursery.

The trial was established in a study area located in the Aguaytía watershed in February 1998. The Aguaytía

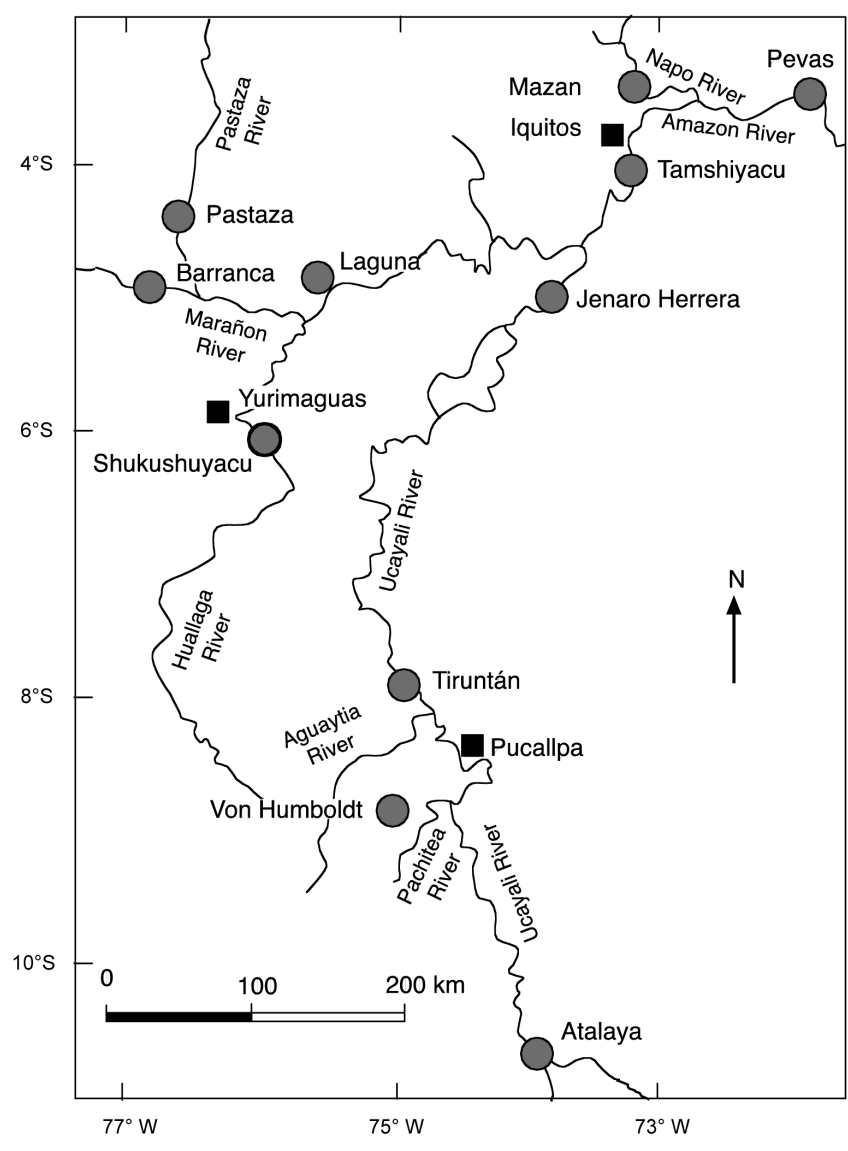

Figure 1. - Geographic location of Calycophyllum spruceanum populations sampled in the Peruvian Amazon for the provenance trial. Locations of the populations are indicated by solid circles. Replications of the trial are located in the lower, middle and upper parts of the Aguaytía watershed, 30-105 km southwest of Pucallpa. Results are presented for seven provenances: Barranca, Pastaza, Laguna, Mazan, Pevas, Tamshiyacu, Jenaro Herrera.

is representative, in terms of rainfall and soils, of many other watersheds in the lowland rainforest of the western Peruvian Amazon. The study area extends from the lower to the upper part of the watershed, i.e. from $30 \mathrm{~km}$ to $105 \mathrm{~km}$ southwest of Pucallpa (see Figure 1 for location of Pucallpa). From the lower to the upper part of the study area, elevation increases from approximately $180 \mathrm{~m}$ to $240 \mathrm{~m}$ above sea level, and annual rainfall increases from approximately $1400 \mathrm{~mm}$ to $2500 \mathrm{~mm}$ ( $\sim 80 \%$ of the range in rainfall among provenance locations). Soils in the lower and middle parts of the study area are very acidic ( $\mathrm{pH} 4$ to $4.5,20$ to $50 \%$ aluminum saturation), with low levels of available phosphorous, and intermediate levels of potassium, calcium and magnesium (Luis Arévalo pers. comm. 2000). Soils in the upper part of the study area are slightly acidic $(\mathrm{pH} 6$ to 6.5) with high levels of available phosphorous, potassium, calcium and magnesium. Soil texture is sandy in the lower part of the study area, heavy with clay in the middle part, and light with organic matter in the upper part. There is a 4-month long dry season with sporadic rains in the study area: during this season (June-September), drought is most severe in the lower part of the watershed and least severe in the upper part of the watershed. 
The experimental design was a randomized incomplete block, with 10 replications. Replications were established in the lower, middle and upper parts of the study area (referred to below as planting zones). Planting zone was considered a classification type variable in the analysis. Replications were established on 10 farms: four in the lower zone, three in the middle zone, and three in the upper zone. The trial was not replicated within farms. In total, 10 provenances were planted in the trial. Provenances were randomly assigned to one of seven square-plots in each replication: 16 trees were planted in each plot, with $2.5 \mathrm{~m}$ spacing between trees and rows. Due to limited numbers of plants, the four southern-most provenances were not tested in all three zones, and were not included in the analyses presented below. The analyses are based on the seven provenances that were tested in all three zones: Laguna, Barranca, Pastaza, Jenaro Herrera, Tamshiyacu, Mazan and Pevas. Five of these provenances were planted in all 10 replications, but two provenances were planted in fewer replications (Laguna in 4 replications, Pevas in 9 replications). Therefore, replications are incomplete blocks with respect to the treatment (provenances).

Replications were kept small ( $\sim 0.125$ ha) to minimize micro-environmental differences within replications, and help ensure that farmers could manage and evaluate their replication. Dead trees were replaced during the first 3 months following trial establishment, but not thereafter. Less than $2 \%$ of the trees died during the 42 month evaluation period.

Farmers' management practices included establishment of a cover crop, minimal application of fertilizer, branch pruning, and manual weeding. Centrosema macrocarpum Benth., a leguminous herb, was sown between rows and $5 \mathrm{~m}$ around the perimeter of each replication to control soil erosion, moderate soil surface temperatures, improve soil fertility, reduce weed invasion, and provide farmers with a cash crop (seed for pastures). Compost ( $1 \mathrm{~kg}$ ) was placed in each planting hole, and rock phosphate $(200 \mathrm{~g})$ was added to the soil around each tree 6 months after planting. No other fertilizers were applied. Branches were pruned from the lower half of the stem 18 months after trial establishment. Weeding was scheduled according to need: every 4 weeks during the rainy season, and every $6-8$ weeks during the dry season. Farmers could weed their replication in 2-3 days when they had available time and labor. However, during periods of peak demand on their time and labor pool, most farmers extended the length of the weeding period, sometimes up to 4 weeks. As a result, weeding was erratically done in most replications, and this undoubtedly produced environmental variation among and within replications (SOTELO Montes et al., 2003).

\section{Traits measured in the provenance trial}

Before thinning, each provenance plot included four interior trees (net plot) and 12 border trees. Trees in the net plot and border undoubtedly experienced different degrees of intra- and inter-provenance competition (Sotelo Montes and Weber, 2001). Since competition is not uniform in farmers' fields, we decided to measure all living trees as an assessment of provenance performance in farmers' fields.

Stem height and diameter were measured on all trees at 30 months, and on the non-thinned trees at 42 months. Height was measured in $\mathrm{cm}$ using a meter stick for trees less than $1 \mathrm{~m}$ in height, and a telescopic measuring pole for taller trees. Stem diameter was measured in $\mathrm{cm}$ at $10 \mathrm{~cm}$ above the soil level using calipers for small trees (mean of two perpendicular measurements) and diameter tape for larger trees (one measurement).

Fifty-percent of the trees in each plot were thinned at the end of the dry season in 2000, 32 months after trial establishment. The trees were coppiced at $30 \mathrm{~cm}$ above soil level. This was a selective thinning based on tree height and bole form (bifurcations in the canopy) using the same selection criteria for all trees, but it was also designed to leave a fairly uniform distribution of trees in the plot. Therefore, the thinned trees were not necessarily the shortest trees and/or trees with bifurcations in the canopy.

The thinned trees were used for analysis of wood density and heat content, and for the correlations between the stem growth and wood traits. Although these trees were not randomly selected from all trees in each plot, it is unlikely that this would affect the general conclusions about the relative magnitude of variation due to provenances and zones, and the correlations between the stem growth and wood traits. There are four reasons that this statement. (1) Wood density was not one of the criteria used to select trees for thinning. (2) Means for height and diameter of the thinned trees were only $8 \%$ lower than the means for all trees, ranging from $5-12 \%$ lower depending on the provenance and zone. Therefore, mean wood density and heat content, and the correlations between these wood traits and tree growth were based on trees that were only slightly smaller than all trees in the trial. Moreover, the coefficient of variation for height and diameter was approximately $45 \%$ for the thinned trees, compared with approximately $41 \%$ for all trees in the trial. (3) Analysis of variance of height and diameter of the thinned trees, using the models presented in the next section, produced essentially the same results as the analysis of variance of all trees, indicating that the thinned trees were representative of all trees in the trial. (4) The frequency of trees with bifurcations in the canopy was $11 \%$ among all trees at the time of thinning, and only slightly higher (15\%) among the thinned trees. There was no statistically significant difference in the frequency of bifurcations among provenances or zones; and there was no statistically significant difference in stem-wood density or heat content between the group of trees with bifurcations and the group of trees without bifurcations (based on analyses of variance, $\mathrm{P}>0.05$ : Weber and Sotelo Montes, unpublished data). It is unlikely, therefore, that this slight increase in the occurrence of canopy bifurcations among the thinned trees would produce any significant bias in the wood traits, in particular since wood samples were obtained from the stem below the canopy.

Discs for the analysis of wood density were sampled from the lower and upper parts of the stem of the 
thinned trees. Two stem sections were collected in the field - one just above the coppice cut, and another just below the live crown. The cut ends of the stem sections were treated with paraffin wax to reduce moisture loss. If possible, six contiguous discs were obtained from each stem section. Prior to preparing the discs, $5 \mathrm{~cm}$ were cut from each end of the stem sections. For the lower stem section, the first disc was sampled near the base (i.e. $35 \mathrm{~cm}$ above ground level) and then five contiguous discs were obtained. Two dimensions were used in order to obtain discs of relatively similar volume from the trees. Disc length was $2.5 \mathrm{~cm}$ for trees with larger stem diameters $(>5 \mathrm{~cm})$, and $5 \mathrm{~cm}$ for trees with smaller stem diameters $(\leq 5 \mathrm{~cm})$. Therefore, the six contiguous discs from the lower stem were sampled from a $30 \mathrm{~cm}$ section for smaller trees and from a $15 \mathrm{~cm}$ section for larger trees (i.e. $35-65 \mathrm{~cm}$ and $35-50 \mathrm{~cm}$ above soil level, respectively). To ensure that the results were not due to this difference in length, we repeated the statistical analyses described below using the mean density for a $15 \mathrm{~cm}$ section (i.e. $35-50 \mathrm{~cm}$ above soil level): means were calculated from a maximum of three discs (each $5 \mathrm{~cm}$ long) for smaller-diameter trees and six discs (each $2.5 \mathrm{~cm}$ long) for larger-diameter trees. The results were entirely consistent with the analysis of six discs, and led to the same conclusions. Therefore, results are presented below for the six discs. For the upper stem section, all discs were $5 \mathrm{~cm}$ in length, so the six contiguous discs were sampled from a $30 \mathrm{~cm}$ section beginning at $5 \mathrm{~cm}$ below the live crown.

Basic density $\left(\mathrm{g} / \mathrm{cm}^{3}\right)$ was determined for each disc using the water-displacement method (ASTM, 1997). Mean density was calculated separately for the lower and upper parts of the stem (discs 1-6 and 7-12, respectively) of each tree, and used in the analyses presented below. The mean number of discs per tree for the lower and upper parts of the stem was 5.91 and 5.88, respectively.

Sawdust, produced during disc preparation, was used to measure heat content. For each tree, sawdust from the lower and upper parts of the stem was thoroughly mixed, and then a sample was obtained from the mixture. Heat content (kilocalories/100 g) was determined from the complete combustion of one sample $(0.3 \mathrm{~g})$ of dry sawdust per tree in an adiabatic bomb calorimeter (ASTM, 1976). Heat content was not adjusted for moisture content, which was approximately $12 \%(+1 \%)$. Detailed methods for determination of wood density and heat content are described elsewhere (Sotelo Montes and WEBER, 2001).

\section{Statistical analysis}

The analyses presented below are based on trees from seven provenances tested in all three planting zones. The following growth and wood traits were analyzed: stem height and diameter at 30 and 42 months; mean wood density in the lower stem and in the upper stem, the difference in mean density between the lower and upper stem, and stem-wood heat content at 32 months. The SAS $^{\circledR}$ statistical package, version 8 (SAS Institute Inc., 1999), was used for all analyses, with $\mathrm{P}<0.05$ considered statistically significant for all tests. The SAS procedures included: GLM, using partial sums of squares (Type III), for analysis of variance; VARCOMP, using the restricted maximum likelihood method (REML), for estimation of variance components; REG for multiple regression; and CORR for Pearson correlations. Transformations of the data were not necessary to satisfy the assumptions of analysis of variance and other analyses.

Variation in growth and wood traits among trees was partitioned by analysis of variance, using a partially hierarchical, mixed model: $\mathrm{Y}_{\mathrm{ijkl}}=\mu+\alpha_{\mathrm{i}}+\beta_{\mathrm{j}(\mathrm{i})}+\gamma_{\mathrm{k}}+\alpha \gamma_{\mathrm{ik}}+$ $\beta \gamma_{\mathrm{j}(\mathrm{i}) \mathrm{k}}+\varepsilon_{\mathrm{ijkl}}$, where $\mathrm{Y}_{\mathrm{ijkl}}=$ tree $_{1}$ in treatment combination $_{\mathrm{ijk}}, \mu=$ the grand mean, $\alpha_{\mathrm{i}}=$ planting zone $_{\mathrm{i}}, \beta_{\mathrm{j}(\mathrm{i})}=$ replication $_{\mathrm{j}}$ nested in zone $_{\mathrm{i}}, \gamma_{\mathrm{k}}=$ provenance $_{\mathrm{k}}, \alpha \gamma_{\mathrm{ik}}=$ interaction between zone $_{\mathrm{i}}$ and provenance $_{\mathrm{k}}, \beta \gamma_{\mathrm{j}(\mathrm{i}) \mathrm{k}}=$ interaction between replication ${ }_{j}$ nested in zone $_{i}$ and provenance ${ }_{\mathrm{k}}$, and $\varepsilon_{\mathrm{ijkl}}=$ residual error. Planting zone was treated as a fixed factor, since each zone is characterized by soil fertility and rainfall conditions. All other sources of variation were treated as random factors. Provenance was considered random because the objective was to evaluate the relative magnitude of variation among provenances from a limited geographical range, rather than to estimate the specific differences among particular provenances. Inference about provenance variation is limited to the geographical region covered by the seven provenances, not to a larger geographical area. Because of the model, some F-ratios involved more than one mean square in the denominator ("quasi" F-ratios), and were tested with approximate degrees of freedom (WINER, 1971). The F-ratios used to test each source of variation in the model had the following forms: planting zone $=\left(\mathrm{MS}_{\text {zone }}\right) /\left(\mathrm{MS}_{\text {rep(zone) }}+\mathrm{MS}_{\text {prov } \mathrm{x} \text { zone }}-\mathrm{MS}_{\text {prov } \mathrm{x}}\right.$ rep(zone) $)$; replication nested in zone $\left(\mathrm{MS}_{\text {rep(zone) }}\right)$, provenance $\left(\mathrm{MS}_{\text {prov }}\right)$, and the provenance-zone interaction $\left(\mathrm{MS}_{\text {prov x zone }}\right)$ were tested over the interaction between provenance and replication nested in zone $\left(\mathrm{MS}_{\text {prov }} \mathrm{x}\right.$ rep(zone) $)$; and this last interaction ( $\mathrm{MS}_{\text {prov } \mathrm{x} \text { rep(zone) }}$ ) was tested over the residual variation $\left(\mathrm{MS}_{\text {residual }}\right)$. Variance components were estimated for each source of variation.

A second analysis of variance model was used to test for significant differences in traits between the eastern (Jenaro Herrera, Tamshiyacu, Mazan, Pevas) and western (Laguna, Barranca, Pastaza) regional groups of provenances. This was also a partially hierarchical, mixed model: $\mathrm{Y}_{\mathrm{ijklm}}=\mu+\alpha_{\mathrm{i}}+\beta_{\mathrm{j}(\mathrm{i})}+\gamma_{\mathrm{k}}+\delta_{\mathrm{l}(\mathrm{k})}+\alpha \gamma_{\mathrm{ik}}+\alpha \delta_{\mathrm{il}(\mathrm{k})}$ $+\beta \gamma_{\mathrm{j}(\mathrm{i}) \mathrm{k}}+\beta \delta_{\mathrm{j}(\mathrm{i})(\mathrm{k})}+\varepsilon_{\mathrm{ijklm}}$, where $\mathrm{Y}_{\mathrm{ijklm}}=$ tree $_{\mathrm{m}}$ in treatment combination $_{\mathrm{ijkl}}, \mu=$ the grand mean, $\alpha_{\mathrm{i}}=$ planting zone ${ }_{\mathrm{i}}$, $\beta_{\mathrm{j}(\mathrm{i})}=$ replication $_{\mathrm{j}}$ nested in zone $_{\mathrm{i}}, \gamma_{\mathrm{k}}=$ region $_{\mathrm{k}}, \delta_{\mathrm{l}(\mathrm{k})}=$ provenance $_{1}$ nested in region ${ }_{\mathrm{k}}, \alpha \gamma_{\mathrm{ik}}=$ interaction between zone $_{\mathrm{i}}$ and region $\mathrm{k}_{\mathrm{k}}, \alpha \delta_{\mathrm{il}(\mathrm{k})}=$ interaction between zone $\mathrm{i}_{\mathrm{i}}$ and provenance $_{1}$ nested in region $\mathrm{k}_{\mathrm{k}}, \beta \gamma_{\mathrm{j}(\mathrm{i}) \mathrm{k}}=$ interaction between replication ${\text { nested in } \text { zone }_{\mathrm{i}} \text { and region }}_{\mathrm{k}}, \beta \delta_{\mathrm{j}(\mathrm{i}) l(\mathrm{k})}$

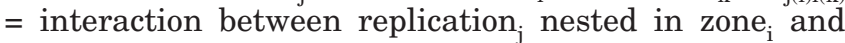
provenance $_{1}$ nested in region $\mathrm{k}_{\mathrm{k}}$, and $\varepsilon_{\mathrm{ijklm}}=$ residual error. Planting zone was a fixed factor, and all other sources of variation were random factors. The F-ratios had the following forms: planting zone $=\left(\mathrm{MS}_{\text {zone }}\right) /\left(\mathrm{MS}_{\text {rep(zone) }}+\right.$ $\left.\mathrm{MS}_{\text {region x zone }}-\mathrm{MS}_{\text {region x rep(zone) }}\right)$; replication nested in zone $=\left(\mathrm{MS}_{\text {rep (zone })}\right) /\left(\mathrm{MS}_{\text {region } \mathrm{x} \text { rep }(\mathrm{zone})}\right) ;$ region $=\left(\mathrm{MS}_{\text {region }}\right) /$ $\left(\mathrm{MS}_{\text {prov(region) }}+\mathrm{MS}_{\text {region x rep(zone) }}-\mathrm{MS}_{\text {prov(region) x rep(zone) }}\right)$; provenance nested in region $=\left(\mathrm{MS}_{\text {prov(region })}\right) /$ 
$\left(\mathrm{MS}_{\text {prov(region) x rep(zone) }}\right)$; interaction between region and zone = $\left(\mathrm{MS}_{\text {region x zone }}\right) /\left(\mathrm{MS}_{\text {region x rep(zone) }}+\mathrm{MS}\right.$

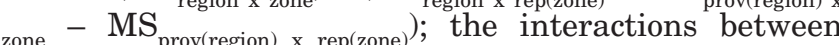
region and replication nested in zone $\left(\mathrm{MS}_{\text {region x rep(zone) }}\right)$, and between provenance nested in region and zone $\left(\mathrm{MS}_{\text {prov(region) } \mathrm{x} \text { zone }}\right)$ were tested over the interaction between provenance nested in region and replication nested in zone $\left(\mathrm{MS}_{\text {prov(region) } \mathrm{x} \text { rep(zone) }}\right)$; and this last interaction $\left(\mathrm{MS}_{\text {prov(region) x rep(zone) }}\right)$ was tested over the residual variation $\left(\mathrm{MS}_{\text {residual }}\right)$.

Latitudinal and longitudinal clines in provenance means for stem growth and wood traits were investigated using Pearson (r) linear correlation coefficients and multiple regression analysis. Independent variables (latitude, longitude, latitude $\mathrm{x}$ longitude interaction, latitude $^{2}$ and longitude ${ }^{2}$ ) for multiple regression were selected using a stepwise method with forward selection. Mean latitude and longitude were computed for each provenance from the latitude and longitude of the 35 mother trees sampled per provenance.

Pearson ( $r$ ) linear correlations among stem growth and wood traits were computed separately within each planting zone to assess the effect of planting zone environment on the correlations.

\section{Results}

Variation in traits due to provenance, environment and their interaction

There was considerable variation in stem-growth traits, but relatively little variation in stem-wood traits. For example, coefficients of variation for all trees in the trial (Table 1A) were approximately $41 \%$ for height and diameter, but only 8-10\% for wood density (higher in upper stem) and $2 \%$ for wood heat content. The coefficient of variation for the difference in wood density between the lower and upper stem was very large $(\sim 150 \%)$ because it involved variation and covariation among two variables, and the mean difference was close to zero. The difference in density was positive for most trees, but approximately $5 \%$ of the trees had slightly greater density in the upper stem.

There was more variation in growth traits in the lower and middle watershed (Table $1 B$ and $C$ : coefficients of variation $29-34 \%$ ) than in the upper watershed (Table $1 D$ : coefficients of variation $13-16 \%$ ). The coefficient of variation is inversely related to mean growth: trees grew more slowly in the lower and middle watershed, which had less fertile soils and lower rainfall, than in the upper watershed, which had the most fertile soils and highest rainfall. The difference in density between the lower and upper stem of the tree showed a similar trend: the coefficient of variation was much larger in the lower and middle watershed $(\sim 190$ to $225 \%$, respectively) where the mean difference was smallest, compared with the upper watershed $(\sim 75 \%)$.

Stem height was the only trait that varied significantly among provenances based on the analysis of variance (not shown). Variation in height among provenances was slightly more significant before thinning $(\mathrm{P}<0.01$ at 30 months) than after thinning ( $\mathrm{P}<0.05$ at 42 months $)$.
Planting zones had a relatively greater effect on stem growth than on wood traits. There were significant differences among zones in height and diameter $(\mathrm{P}<0.001)$ and, to a less extent, in wood density from the upper stem and the difference in wood density between the lower and upper stem $(\mathrm{P}<0.05)$. Height, diameter and the difference in wood density between the lower and upper stem were greatest in the upper watershed, while wood density from the upper stem was greatest in the lower watershed (Table 1).

For stem height and diameter, planting zones accounted for much more variation than did provenances. Considering height, for example, the variance component for provenances was approximately $2 \%$ of the total variance at 30 and 42 months, whereas variance due to zones increased from approximately $60 \%$ to $67 \%$ over the same period.

There was no significant interaction between provenances and planting zones for any trait, indicating that differences among provenance means were relatively stable across zones. However, there was a significant interaction between provenances and replications within zones for most traits $(\mathrm{P}<0.001$ for height, diameter, wood density in lower stem; $\mathrm{P}<0.05$ for difference in density between lower and upper stem, and wood heat content). In addition, there were significant differences among replications within zones for most traits $(\mathrm{P}<0.001$ for height, diameter, wood heat content; $\mathrm{P}<0.01$ for wood density in upper stem). The large variances due to replications and interactions between provenances and replications were the result of farmers' erratic management practices, as reported elsewhere (Sotelo Montes et al., 2003). The large provenancereplication interaction made it difficult to detect statistically significant differences among provenances.

Provenance rankings based on stem growth were quite stable throughout the 42-month evaluation period. For example, throughout this period Barranca ranked first in mean height, while Laguna, Pastaza and Pevas remained the slowest-growing provenances (Figure 2). Mazan and Jenarro Herrera changed ranks after the thinning due to a difference in the distribution of tree height before thinning (positively skewed for Mazan, not skewed for Jenarro Herrera).

There was no significant difference in any stem growth or wood trait between the eastern (Jenaro Herrera, Tamshiyacu, Mazan, Pevas) and western (Laguna, Barranca, Pastaza) regional groups of provenances (analysis of variance not shown). The interaction between the regional groups and planting zone also was not significant.

\section{Clinal variation in traits}

Correlation and regression analysis indicated a possible cline in stem-wood heat content. Mean heat content for provenances increased slightly with provenance latitude/longitude, i.e. from the wetter, northeastern part of the sample region, near the equator, to the drier, southwestern part of the sample region (regression slope for latitude-longitude interaction $=0.0238$, standard error $=$ 0.0047 , model $\mathrm{R}^{2}=0.84$, model $\mathrm{Df}=1$ and $5, \mathrm{P}<0.01$; 
Table 1. - Descriptive statistics of stem growth and wood traits in a provenance trial of Calycophyllum spruceanum.

\begin{tabular}{|c|c|c|c|c|c|}
\hline Trait & Mean & St. dev. & Minimum & Maximum & Number \\
\hline \multicolumn{6}{|l|}{ Stem height (m) } \\
\hline 30 months & 4.71 & 1.94 & 1.15 & 9.86 & 990 \\
\hline 42 months & 5.74 & 2.39 & 1.60 & 12.26 & 502 \\
\hline \multicolumn{6}{|l|}{ Stem diameter $(\mathrm{cm})$} \\
\hline 30 months & 7.79 & 3.11 & 1.38 & 17.97 & 990 \\
\hline 42 months & 8.95 & 3.56 & 2.50 & 18.60 & 502 \\
\hline \multicolumn{6}{|l|}{ Stem wood density $\left(\mathrm{g} / \mathrm{cm}^{3}\right)-32$ months } \\
\hline Upper stem & 0.525 & 0.055 & 0.272 & 0.717 & 496 \\
\hline Lower stem & 0.563 & 0.046 & 0.348 & 0.733 & 498 \\
\hline Difference lower minus upper stem & 0.038 & 0.057 & -0.248 & 0.205 & 496 \\
\hline Stem wood heat content $(\mathrm{kcal} / 100 \mathrm{~g})-32$ months & 425.6 & 8.4 & 396.4 & 459.6 & 500 \\
\hline \multicolumn{6}{|l|}{ B. Trees in the lower watershed } \\
\hline Trait & Mean & St. dev. & Minimum & Maximum & Number \\
\hline \multicolumn{6}{|l|}{ Stem height (m) } \\
\hline 30 months & 3.94 & 1.28 & 1.15 & 7.50 & 391 \\
\hline 42 months & 4.65 & 1.42 & 1.60 & 8.48 & 199 \\
\hline \multicolumn{6}{|l|}{ Stem diameter $(\mathrm{cm})$} \\
\hline 30 months & 6.68 & 2.27 & 1.38 & 14.19 & 391 \\
\hline 42 months & 7.52 & 2.39 & 2.50 & 17.20 & 199 \\
\hline \multicolumn{6}{|l|}{ Stem wood density $\left(\mathrm{g} / \mathrm{cm}^{3}\right)-32$ months } \\
\hline Upper stem & 0.545 & 0.051 & 0.351 & 0.701 & 198 \\
\hline Lower stem & 0.573 & 0.044 & 0.369 & 0.727 & 198 \\
\hline Difference lower minus upper stem & 0.028 & 0.054 & -0.149 & 0.178 & 198 \\
\hline Stem wood heat content $(\mathrm{kcal} / 100 \mathrm{~g})-32$ months & 426.3 & 8.6 & 405.4 & 459.6 & 198 \\
\hline \multicolumn{6}{|l|}{ C. Trees in the middle watershed } \\
\hline Trait & Mean & St. dev. & Minimum & Maximum & Number \\
\hline \multicolumn{6}{|l|}{ Stem height $(\mathrm{m})$} \\
\hline 30 months & 3.37 & 1.11 & 1.40 & 6.65 & 295 \\
\hline 42 months & 4.16 & 1.36 & 2.20 & 8.65 & 151 \\
\hline \multicolumn{6}{|l|}{ Stem diameter $(\mathrm{cm})$} \\
\hline 30 months & 5.40 & 1.78 & 1.78 & 10.90 & 295 \\
\hline 42 months & 6.42 & 1.84 & 3.20 & 12.90 & 151 \\
\hline \multicolumn{6}{|l|}{ Stem wood density $\left(\mathrm{g} / \mathrm{cm}^{3}\right)-32$ months } \\
\hline Upper stem & 0.515 & 0.057 & 0.272 & 0.717 & 148 \\
\hline Lower stem & 0.540 & 0.048 & 0.348 & 0.680 & 150 \\
\hline Difference lower minus upper stem & 0.025 & 0.059 & -0.248 & 0.201 & 148 \\
\hline Stem wood heat content $(\mathrm{kcal} / 100 \mathrm{~g})-32$ months & 422.7 & 8.2 & 396.4 & 440.3 & 150 \\
\hline \multicolumn{6}{|l|}{ D. Trees in the upper watershed } \\
\hline Trait & Mean & St. dev. & Minimum & Maximum & Number \\
\hline \multicolumn{6}{|l|}{ Stem height $(\mathrm{m})$} \\
\hline 30 months & 6.99 & 1.10 & 1.99 & 9.86 & 304 \\
\hline 42 months & 8.73 & 1.16 & 5.70 & 12.26 & 152 \\
\hline \multicolumn{6}{|l|}{ Stem diameter $(\mathrm{cm})$} \\
\hline 30 months & 11.20 & 1.76 & 3.28 & 17.97 & 304 \\
\hline 42 months & 13.32 & 1.72 & 8.80 & 18.60 & 152 \\
\hline \multicolumn{6}{|l|}{ Stem wood density $\left(\mathrm{g} / \mathrm{cm}^{3}\right)-32$ months } \\
\hline Upper stem & 0.507 & 0.047 & 0.278 & 0.665 & 150 \\
\hline Lower stem & 0.573 & 0.039 & 0.477 & 0.733 & 150 \\
\hline Difference lower minus upper stem & 0.066 & 0.049 & -0.116 & 0.205 & 150 \\
\hline Stem wood heat content $(\mathrm{kcal} / 100 \mathrm{~g})-32$ months & 427.5 & 7.6 & 410.3 & 445.3 & 152 \\
\hline
\end{tabular}

Pearson $\mathrm{r}$ with latitude $=0.90, \mathrm{P}<0.01, \mathrm{n}=7$; Pearson $\mathrm{r}$ with longitude $=0.86, \mathrm{P}<0.05, \mathrm{n}=7$ ). None of the other traits was significantly correlated with latitude or longitude.

\section{Correlations among traits}

Most correlations between stem growth and wood traits were significant, but weak, in the lower watershed (Table 2A) and not significant in the middle and upper watersheds (Table $2 B, C$ ). Correlations are summarized below for each planting zone.

Correlations between stem growth and wood density differed in magnitude and sign among the planting zones. In the lower watershed, stem height and diameter were negatively correlated with wood density in both the lower and upper stem (Table 2A), indicating that larger trees tended to have lower wood density in both parts of the stem, compared with smaller trees. Correlations between growth and wood density were not significant in the middle watershed (Table $2 B$ ). However, in the upper watershed diameter was positively correlated with wood density in the lower stem and the other correlations were not significant (Table 2C).

The difference in wood density between the lower and upper stem was positively correlated with stem height and diameter in the upper watershed (Table $2 \mathrm{C}$ ), indicating that larger trees tended to have a greater difference in density between the lower and upper stem. Correlations in the other two planting zones were not significant. Correlations with density in the lower stem 


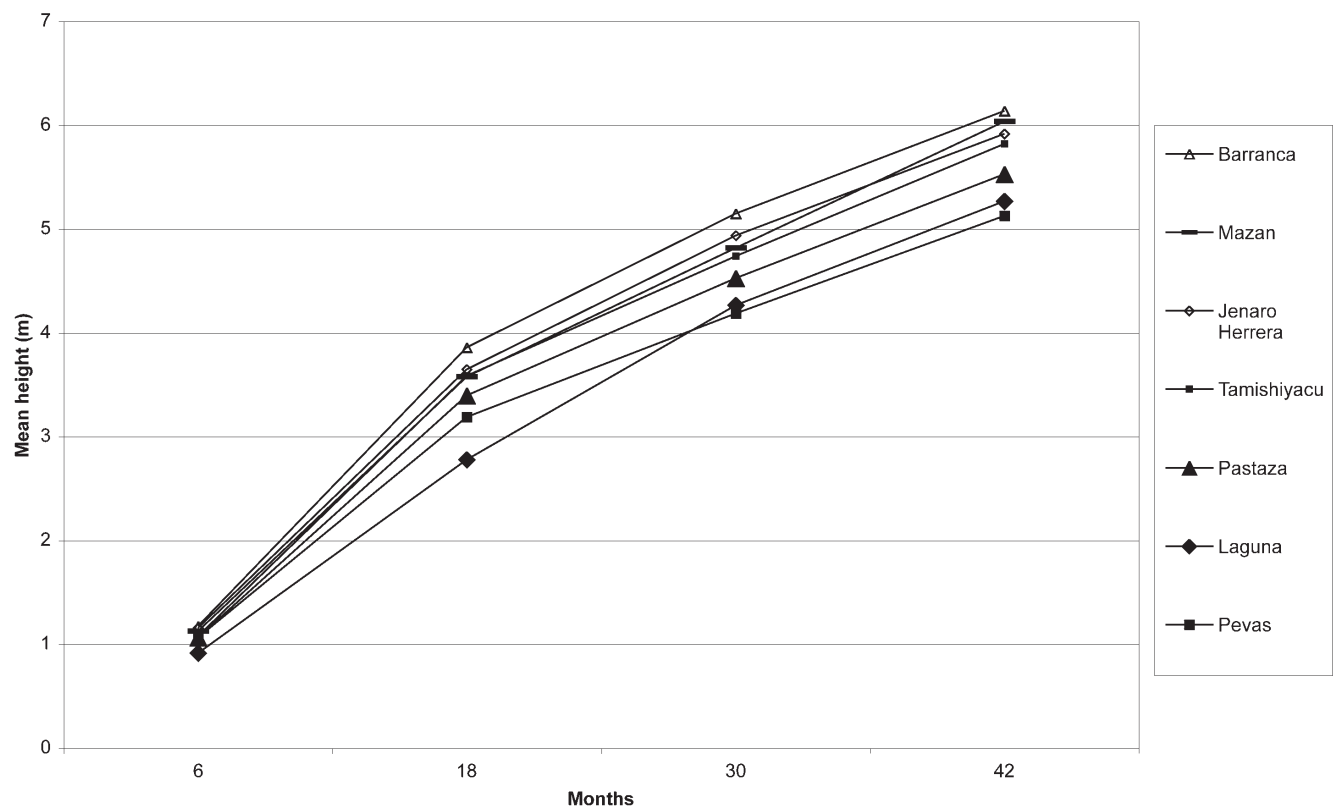

Figure 2. - Mean stem height of seven provenances of Calycophyllum spruceanum evaluated at 6 , 18,30 and 42 months.

Table 2. - Pearson (r) correlation coefficients among stem growth and wood traits in three planting zones of a provenance trial of Calycophyllum spruceanum. Asterisks indicate significance of correlation coefficients: *** $\mathrm{P}<0.001$, ** $\mathrm{P}<0.01$, $* \mathrm{P}<0.05$, NS P $>0.05$.

A. Trees in the lower watershed

\begin{tabular}{|c|c|c|c|c|c|c|}
\hline & Stem height & Stem diameter & $\begin{array}{c}\text { Density } \\
\text { lower stem }\end{array}$ & $\begin{array}{c}\text { Density } \\
\text { upper stem }\end{array}$ & $\begin{array}{c}\text { Density } \\
\text { lower - upper }\end{array}$ & Heat content \\
\hline Stem height & --- & & & & & \\
\hline Stem diameter & $0.88 * * *$ & --- & & & & \\
\hline Wood density & $-0.25 * * *$ & $-0.25 * * *$ & & & & \\
\hline lower stem & & & --- & & & \\
\hline $\begin{array}{l}\text { Wood density } \\
\text { upper stem }\end{array}$ & $-0.17 *$ & $-0.19 * *$ & $0.37 * * *$ & --- & & \\
\hline $\begin{array}{l}\text { Wood density } \\
\text { lower - upper stem }\end{array}$ & $-0.04 \mathrm{NS}$ & $-0.02 \mathrm{NS}$ & $0.48 * * *$ & $-0.65 * * *$ & --- & \\
\hline Wood heat content & $0.36 * * *$ & $0.32 * * *$ & $-0.29 * * *$ & $-0.13 \mathrm{NS}$ & $-0.12 \mathrm{NS}$ & --- \\
\hline
\end{tabular}

Notes: $\mathrm{N}=391$ for the correlation stem height-diameter, and ranges from 191 to 198 for other correlations.

B. Trees in the middle watershed

\begin{tabular}{|c|c|c|c|c|c|c|}
\hline & Stem height & Stem diameter & $\begin{array}{c}\text { Density } \\
\text { lower stem }\end{array}$ & $\begin{array}{c}\text { Density } \\
\text { upper stem }\end{array}$ & $\begin{array}{c}\text { Density } \\
\text { lower - upper }\end{array}$ & Heat content \\
\hline Stem height & --- & & & & & \\
\hline Stem diameter & $0.89 * * *$ & --- & & & & \\
\hline $\begin{array}{l}\text { Wood density } \\
\text { lower stem }\end{array}$ & $0.12 \mathrm{NS}$ & $0.10 \mathrm{NS}$ & --- & & & \\
\hline $\begin{array}{l}\text { Wood density } \\
\text { upper stem }\end{array}$ & 0.04 NS & $-0.03 \mathrm{NS}$ & $0.34 * * *$ & --- & & \\
\hline $\begin{array}{l}\text { Wood density } \\
\text { lower - upper stem }\end{array}$ & $0.03 \mathrm{NS}$ & $0.08 \mathrm{NS}$ & $0.43 * * *$ & $-0.70 * * *$ & --- & \\
\hline Wood heat content & $0.13 \mathrm{NS}$ & $0.22 * *$ & $-0.04 \mathrm{NS}$ & $-0.18 *$ & $0.12 \mathrm{NS}$ & --- \\
\hline
\end{tabular}

Notes: $\mathrm{N}=295$ for the correlation stem height-diameter, and ranges from 142 to 150 for other correlations.

C. Trees in the upper watershed

\begin{tabular}{|c|c|c|c|c|c|c|}
\hline & Stem height & Stem diameter & $\begin{array}{c}\begin{array}{c}\text { Density } \\
\text { lower stem }\end{array} \\
\end{array}$ & $\begin{array}{c}\text { Density } \\
\text { upper stem }\end{array}$ & $\begin{array}{c}\text { Density } \\
\text { lower - upper }\end{array}$ & Heat content \\
\hline Stem height & --- & & & & & \\
\hline Stem diameter & $0.66 * * *$ & --- & & & & \\
\hline $\begin{array}{l}\text { Wood density } \\
\text { lower stem }\end{array}$ & $0.13 \mathrm{NS}$ & $0.19 *$ & --- & & & \\
\hline $\begin{array}{l}\text { Wood density } \\
\text { upper stem }\end{array}$ & $-0.11 \mathrm{NS}$ & $-0.07 \mathrm{NS}$ & $0.35 * * *$ & --- & & \\
\hline $\begin{array}{l}\text { Wood density } \\
\text { lower - upper stem }\end{array}$ & $0.21 *$ & $0.21 * *$ & $0.45 * * *$ & $-0.68 * * *$ & --- & \\
\hline Wood heat content & $0.18 *$ & $0.12 \mathrm{NS}$ & $-0.05 \mathrm{NS}$ & $-0.03 \mathrm{NS}$ & $-0.01 \mathrm{NS}$ & --- \\
\hline
\end{tabular}


(positive) and upper stem (negative) simply reflect how the difference was calculated.

Correlations between stem growth and stem-wood heat content were positive in all three planting zones, indicating that the wood of larger trees tended to have higher heat content, compared with smaller trees. The correlation with heat content was significant for both stem height and diameter in the lower watershed (Table $2 A$ ), but only for diameter in the middle watershed (Table 2B) and height in the upper watershed (Table $2 C)$.

The correlation between stem-wood density and heat content was negative, indicating that denser wood tended to have lower heat content, but the correlation was significant in only the lower and middle watershed (Table 2A, B). The correlation was significant with density in the lower stem only in the lower watershed, and with density in the upper stem only in the middle watershed.

\section{Discussion}

The principal results are discussed in four sections: variation in stem growth, variation in stem-wood density and heat content, clinal variation in stem-wood heat content, and correlations between growth and wood traits.

\section{Variation in stem growth}

Results confirm that there is potential for selection of fast-growing provenances of Calycophyllum spruceanum at an early age in the Peruvian Amazon. There was significant variation in stem height among provenances at both 30 and 42 months. Variation among provenances was also significant at 6, 12 (SOTELO MonTEs et al., 2000) and 18 months (Sotelo Montes et al., 2003), and provenance rankings have remained quite stable throughout the 42-month evaluation period. These results are noteworthy because differences among provenances often take a long time to be expressed (MORGENSTERN, 1996); analyses were based on only seven provenances from a relatively small region near the equator; and farmers' erratic management practices produced significant interactions between provenances and replications, making it difficult to detect statistically significant differences among provenances. When conducting trials on farms, farmers' management practices cannot be controlled as rigorously as in a trail established on an experiment station (STERN et al., 2004). Therefore, there is more error variance, and this often makes it difficult to detect statistically significant differences among treatments.

Planting zones accounted for much more variation in tree growth than did provenances. For example, the range in mean height at 42 months was $4.6 \mathrm{~m}$ among the three planting zones, but only $1.0 \mathrm{~m}$ among the seven provenances. Therefore, the greatest gains in tree growth can be realized first by selecting the best planting zone, and second by selecting the fastest growing and best adapted provenance for that zone. Based on this study, planting zones with high rainfall and fertile soils (like the upper watershed) clearly produce faster tree growth. Among the seven provenances studied, the Barranca provenance had the best overall growth across zones, and there was no significant interaction between provenances and zones. The Barranca provenance also produced the tallest shoots following the coppice cut at 32 months (BoIVIN-СНАвот et al., 2004).

There was relatively more variation in tree growth in the planting zones with lower rainfall and less fertile soils (lower and middle watershed) than in the zone with the highest rainfall and most fertile soils (upper watershed). This could reflect two interacting factors. Farmers' erratic weeding practices undoubtedly produced considerable spatial and temporal variation in soil moisture, temperature and fertility within the replications. One would expect this micro-environmental variation to produce greater differences in growth among neighboring trees in a zone of low rainfall and infertile soils than in a zone of high rainfall and fertile soils. Second, if there is phenotypic variation in drought tolerance mechanisms among trees, one would expect greater variation to be expressed among trees planted in the drier planting zones. Leaf abscission during the dry season is one drought tolerance mechanism to control water loss and postpone dehydration (KozLOWsKI et al., 1991). In the upper watershed, partial abscission in the upper canopy was rarely observed among trees in the replications: most trees maintained leaves throughout the canopy during the dry season. But in the lower and middle watershed, neighboring trees within the replications varied from partial to complete leaf abscission during the dry season. Since leaf abscission reduces the photosynthetic surface, variation in leaf abscission among neighboring trees could produce substantial variation in growth rates.

\section{Variation in stem-wood density and heat content}

Stem-wood density and heat content were within the range reported for 32 other species in the Peruvian Amazon (UCEDA, 1984; TARANCO MARABOTTO et al., 1991; MejIA and UcedA, 1992; Mori, 1994; Sotelo Montes and WEBER, 2001), but intra-specific variation has not been studied in these other species. Mean stem-wood density at 32 months was approximately $10 \%$ greater than mean branch-wood density at 18 months $(0.544$ versus $0.494 \mathrm{~g} / \mathrm{cm}^{3}$ ), whereas mean heat content was nearly identical for stems and branches (425.6 versus $425.01 \mathrm{kcal} / 100 \mathrm{~g})$ (18-month data from Sotelo MonTES et al., 2003).

Stem-wood density and heat content did not vary significantly among provenances, suggesting that there is little potential for direct selection of superior provenances based on these wood properties. PEREIRA and LAVORANTI (1986) also reported no significant variation in wood density and other characteristics related to charcoal potential (lignin content, yield of distillates, fixed carbon and volatiles) among three provenances of Mimosa scabrela Benth. in Brazil. However, the lack of significant variation among provenances may be due to the limited geographical and environmental range among the provenances included in this study. For example, significant variation in wood density among 
provenances from a larger geographical range was reported for Racosperma auriculiforme Cunn. ex Benth. and R. mangium Willd. (KHASA et al., 1995), Sterculia apetala (Jacq.) Karst. (DvorAK et al., 1998), Eucalyptus globulus Labill. (MIRANDA et al., 2001), and Gmelina arborea Linn. Roxb. (LAURIDSEN and KJÆR, 2002).

Mean wood density of all trees was slightly greater in the lower stem than in the upper stem $(\sim 7 \%$ difference). In discussing the mechanical design of trees, MosBRUGGER (1990) notes that the base of the tree has the highest bending stress, and this stress can be reduced by increasing the strength of supporting tissue at the base of the tree. Strength can be increased by producing denser wood (with a greater Young's modulus of elasticity) at the base of the tree, as shown experimentally for Robinia pseudoacacia L. (NIKLAS, 1997). Denser wood at the base of trees of Calycophyllum spruceanum, therefore, may be a mechanical design solution to alleviate bending stress in this species. However, wood density is known to increase from the base to the crown in some hardwood species (ZoBEL and vAN BUIJTENEN, 1989), and in this trial approximately $5 \%$ of the trees had slightly denser wood in the upper stem.

Environmental differences among planting zones produced significant differences in wood density in the upper stem and in the difference in density between the lower and upper stem, but no significant difference in wood density in the lower stem. Mean density in the upper stem was lowest in the zone with the highest rainfall, most fertile soils and most rapid tree growth (upper watershed), and highest in the zone with the lowest rainfall, infertile soils and slower tree growth (lower watershed). This agrees with the results of several other studies showing that wood density is often greater in zones where trees grow slowly, and lower in zones where trees grow more rapidly (BARAJAS-MORALES, 1987; PAROLIN and FERREIRA, 1998; WoODCOCK et. al., 2000; WiEMANN and WiLLIAMSON, 2002), although there are exceptions to this general pattern (DETIENNE and CHANson, 1996). The difference in density between the lower and upper stem of the trees was also largest in the planting zone where trees grew most rapidly. This is consistent with mechanical design considerations (MosBRUGGER, 1990): as trees grow taller, they should increase the strength at the base of the stem (i.e. produce wood with higher density) and increase the flexibility in the upper stem (i.e. produce wood with low density). One would expect, therefore, to observe the largest difference in density between the lower and upper stem in an environment where trees grow most rapidly.

The results of this study demonstrate that large environmental differences have a relatively greater effect on density in the upper stem than in the lower stem. These environmental effects have a practical implication: planting trees of Calycophyllum spruceanum in zones of slower growth may produce denser wood with less variation between the lower and upper stem; whereas planting trees in zones of rapid growth may produce lower wood density in the upper stem, and a larger difference in density between the lower and upper stem. Larger differences in density within the stem could result in less uniformity in physical and mechanical properties of the wood (NIKLAS, 1997), and lower commercial value.

\section{Clinal variation in stem-wood heat content}

Stem-wood heat content varied clinally, increasing slightly from the wetter, northeastern part of the sample region to the relatively drier, southwestern part of the sample region. A similar cline was observed in branchwood heat content at 18 months (SOTELO MONTES et al., 2003), and the authors proposed an hypothesis that related the wood's heat content to its protective chemicals. Heat content of the wood depends on its water content and chemical composition, especially the content of lignin, resins, terpenes and essential oils (ELVIRA and HERNANDO, 1989). Some of these chemicals may have a secondary protective function (ZANGERL and BAZZAZ, 1992). In theory, more protective chemicals in the wood may be expected in populations that occur in more stressful environments. The cline in stem-wood heat content, therefore, may reflect an underlying cline in protective chemicals from the wetter to the relatively drier part of the sample region. The wood of Calycophyllum spruceanum contains gums (JUNAC, 1981), but the chemical composition of the wood has not been extensively analyzed. However, other results of this study are not consistent with this hypothesis. If the hypotheses were correct, one would expect the stem-wood heat content to be higher in the lower watershed than in the upper watershed, but this was not observed.

\section{Correlations between stem growth and wood traits}

Correlations between stem growth and wood density in Calycophyllum spruceanum differed in sign among planting zones, suggesting that selection of fast-growing trees could indirectly reduce wood density on dry sites (lower watershed) but not on moist sites (upper watershed). However, selection of fast-growing trees on moist sites could indirectly increase the difference in wood density between the lower and upper stem. In contrast, correlations between stem growth and stem-wood heat content were positive in all zones studied, suggesting that selection of fast-growing trees would not reduce the wood's heat content. All the statistically significant correlations were weak, however, suggesting that selection of fast-growing trees would have a very small effect on stem-wood density and heat content.

Correlations between growth and wood density have been studied in many tree species, with contrasting results that depend on the species (ZOBEL and JETT, 1995). For example, DvoraK and others (1998) reported a weak, positive phenotypic correlation between stem growth and wood density of Sterculia apetala in Columbia, and BHAT (2000) reported that fast-growing provenances of Tectona grandis $\mathrm{L}$. could be selected without reducing wood density. RocHON (2004), however, found a strong, negative phenotypic correlation between stem growth and wood density of Guazuma crinita Mart. in Peru.

Results from this study illustrate that the test environment can also affect the correlation. These are phenotypic correlations, which reflect both genetic and 
environmental effects, so the magnitude and even the sign may vary among test environments (STEARNS, 1989; FALCONER and MACKAY, 1996). Phenotypic and genetic correlations generally have the same sign, but they may vary in magnitude. For example, in a progeny test of Eucalyptus grandis Hill ex Maiden, the phenotypic correlation between tree growth rate and wood density in South Africa was not significant, suggesting that there would be no correlated response in wood density if selection were based on growth rate; but the genetic correlation was negative and significant, indicating that selection for growth rate would reduce stem wood density (MALAN, 1991).

\section{Conclusions}

This is the first provenance trial of C. spruceanum, and inference about variation among provenances cannot be extrapolated beyond the sample region in the Peruvian Amazon. Nevertheless, the expression of variation among provenances from a relatively limited geographical and environmental range, at an early age, and despite "un-controlled" variation produced by farmers' management practices, indicates that there is potential to select fast-growing provenances in the Peruvian Amazon. However, the effect of planting zone is much greater than the effect due to these provenances. Moreover, there may be a trade-off between stem growth and wood density in some planting zones. A progeny test of $C$. spruceanum is underway in different planting zones in the Aguaytía watershed of Peru (SoTElo Montes, unpublished data): this test will provide estimates of genetic correlations that are necessary to determine if early selection based on growth rate will affect wood quality traits.

\section{Acknowledgements}

This research was supported by grants to the World Agroforestry Centre from the Interamerican Development Bank; the Government of Spain; the Governments of Netherlands and Norway as part of the CGIAR Global Initiative for Alternatives to Slash and Burn; the Department for International Development of the United Kingdom; and Winrock International as part of the USAID Alternative Development Program. The authors sincerely thank the farmers and technicians who worked on this project, Nancy Mandel (U.S.D.A. Forest Service) for statistical advice, and two anonymous reviewers for their useful comments and suggestions.

\section{References}

Acevedo, M. and Y. KiKATA (1994): Atlas de Maderas del Perú. Universidad de Nagoya, Japón, Universidad Nacional Agraria La Molina, Lima, Per.

ASTM (1976): Standard test method for gross calorific value of solid fuel by the adiabatic bomb calorimeter. In: Annual Book of ASTM Standards pp. 290-297. American Society for Testing and Materials, Philadelphia PA, USA.

ASTM (1997): Standard test methods for specific gravity of wood and wood-base materials. In: Annual book of ASTM Standards, 4.10, pp. 348-355. Philadelphia, USA.
BARAJAS-Morales, J. (1987): Wood specific gravity in species from two tropical forests in Mexico. IAWA Bulletin 8: $143-148$.

BнAт, K. M. (2000): Timber quality of teak from managed tropical plantations with special reference to Indian plantations. Bois et Forêt 263: 6-16.

Boivin-Chabot, S., H. A. Margolis and J. C. Weber (2004): Variation in coppice-shoot growth among provenances of Calycophyllum spruceanum Benth. in the Peruvian Amazon Basin. Forest Ecology and Management 198: 249-260.

Detienne, P. and B. Chanson (1996): L'éventail de la densité du bois des feuillus - comparaison entre différentes régions du monde. Bois et Forêts des Tropiques 250: 19-29.

Dvorak, W. S., H. Uruena, L. A. Moreno and H. Goforth (1998): Provenance and family variation in Sterculia apetala in Colombia. Forest Ecology and Management 111: $127-135$.

ElviRA, L. M. and C. HeRnANDo (1989): Inflamabilidad y energía de las especies de sotobosque. Instituto Nacional de Investigaciones Agrarias, Madrid, Spain. 99 p.

FALCONER, D. S. and T. F. C. MACKAY (1996): Introduction to Quantitative Genetics. Addison Wesley Longman Limited, Edinburgh, UK.

JUNAC (1981): Descripción General y Anatómica de 105 Maderas del Grupo Andino. Junta del Acuerdo de Cartagena (JUNAC), Lima, Perú. pp. 29-31.

Kalliola, R., M. Puhakka and W. Danjoy (Eds.) (1993): Amazonía Peruana - Vegetación Húmeda Tropical en el Llano Subandino. Proyecto Amazonía Universidad de Turku, Oficina Nacional de Evaluación de Recursos Naturales, Lima, Perú. 265 p.

Khasa, P. D., P. Li, G. Vallée, S. Magnussen and J. BousQUET (1995): Early evaluation of Racosperma auriculiforme and $R$. mangium provenance trials on four sites in Zaire. Forest Ecology and Management 78: 99-113.

Kozlowski, T. T., P. J. Kramer and S. G. Pallardy (1991): The Physiological Ecology of Woody Plants. Academic Press, Inc., New York, USA. 657 p.

LABARTA, R. A. and J. C. WeBER (1998): Valorización económica de bienes tangibles de cinco especies arbóreas agroforestales en la Cuenca Amazónica Peruana. Revista Forestal Centroamericana 23: 12-21.

LAURANCE, W. F. (2001): The hyper-diverse flora of the central Amazon: an overview. In: BIERREGAARD, R. O, Lovejoy, T. E., Gascon, C., Mesquita, R., Wilson, E. O. and SAlati, E. (Eds.): Lessons from Amazonia: Ecology and Conservation of a Fragmented Forest. Yale University Press. New Haven, CO, USA. pp. 47-53.

LAURIDSEN, E. B and E. D. KJÆR (2002): Provenance research in Gmelina arborea Linn. Roxb. A summary of results from three decades of research and a discussion of how to use them. International Forestry Review 4: 20-29.

Linares, C., E. Meneses and J. DiAz (1992): Monografia sobre capirona: Calycophyllum spruceanum. Proyecto Forestal ITTO PD 37/88 Utilización industrial de nuevas especies forestales en el Perú. Camara Nacional Forestal, Dirección General de Forestal y Fauna, Lima, Perú. 32 p.

MALAN, F. S. (1991): Variation, association and inheritance of juvenile wood properties of Eucalyptus grandis Hill ex Maiden with special reference to the effect of growth. South African Forestry Journal 157: 16-23.

Mejia, N. E. and M. UCEdA (1992): Poder calorífico de cinco especies de Bombacaceas. Revista Forestal Perú 19: 93-97. 
Miranda, I., M. H. Almeida and H. Pereira (2001): Influence of provenance, subspecies, and site on wood density in Eucalyptus globulus Labill. Wood and Fiber Science 33: 9-15.

Morgenstern, E. K. (1996): Geographic Variation in Forest Trees - Genetic Basis and Application of Knowledge in Silviculture. University of British Columbia Press, Vancouver BC, Canada. 208 p.

MORI, J. (1994): Influencia de la temperatura en los productos de destilación seca de seis maderas de la zona de Jenaro Herrera Loreto. Tesis de Ingeniero Forestal. Universidad Nacional Agraria La Molina, Lima, Perú. $131 \mathrm{p}$.

Mosbrugger, V. (1990): The Tree Habit in Land Plants. Lecture Notes in Earth Sciences. Edited by BHATtacharJi, S., Friedman, G. M., Neugebauer, H. J. and A. SEILACHER. Springer-Verlag, Berlin. 158 p.

NIKLAS, K. J. (1997): Size- and age-dependent variation in the properties of sap- and heartwood in Black Locust (Robinia pseudoacacia L.). Annals of Botany 79: 473-78.

Parolin, P. and L. V. Ferreira (1998): Are there differences in specific wood gravities between trees in várzea and igapó (Central Amazonia)? Ecotropica 4: 25-32.

PereirA, J. C. D. and O. J. LAVoranti (1986): Comparison of wood quality of three provenances of Mimosa scabrella Benth. for energy purposes. Boletim de Pesquisa Florestal 12: 30-34. Centro Nacional de Florestas, Empresa Brasileira de Pesquisa Agropecuária (EMBRAPA), Brasilia, Brasil.

Pinedo-Vasquez, M., D. Zarin, K. Coffey, C. Padoch and F. RABELO (2001): Post-boom timber production in Amazonia. Human Ecology 29: 219-239.

Rochon, C. (2004): Croissance et densité du bois de sept provenances de Guazuma crinita Mart. dans le bassin de l'Amazonie péruvienne. M.S. thesis, Département des Sciences du Bois et de la Forêt, Université Laval, Québec, Canada. 108 p.

SAS INSTITUTE INC. (1999): SAS/STAT Users' Guide, Version 8. SAS Institute Inc., Cary, NC, USA. 3884 p.

SEARS, R. R. (2003): New forestry on the floodplain: the ecology and management of Calycophyllum spruceanum (Rubiaceae) on the Amazon landscape. PhD dissertation, Graduate School of Arts and Sciences, Columbia University, Ithaca, New York, USA. 246 p.

Sotelo Montes, C. and J. C. Weber (1997): Priorización de especies arbóreas para sistemas agroforestales en la selva baja del Perú. Agroforestería en las Américas 4: 12-17.

Sotelo Montes, C., H. Vidaurre, J. C. Weber, A. J. Simons and I. DAWSON (2000): Producción de semillas a partir de la domesticación participativa de árboles agroforestales en la amazonía peruana. In: SALAZAR, R. (Ed.): Memorias del Segundo Symposio sobre Avances en la Producción de Semillas Forestales en América Latina. Proyecto de Semillas Forestales (PROSEFOR), Centro de Agricultura Tropical y de Enseñanza (CATIE), International Union of Forest Research Organizations (IUFRO), Santo Domingo, República Domínica. pp. $65-72$.
Sotelo Montes, C. and J. C. Weber (2001): Variation in growth and wood traits among provenances of Calycophyllum spruceanum Benth. from the Peruvian Amazon. Research Report for the International Tropical Timber Organization, Fellowship Programme Reference 090/99A. International Centre for Research in Agroforestry, Lima, Peru. $73 \mathrm{p}$.

Sotelo Montes, C., H. VidaurRe and J. C. Weber (2003): Variation in stem-growth and branch-wood traits among provenances of Calycophyllum spruceanum Benth. from the Peruvian Amazon. New Forests 26: $1-16$.

StEarns, S. C. (1989): The evolutionary significance of phenotypic plasticity. Biological Science 39: 436-45.

Stern, R. D., R. Coe, E. F. Allan and I. C. Dale (Eds.) (2004): Good Statistical Practice for Natural Resources Research. CABI Publishing, CAB International, Wallingford, U.K. 388 p.

Taranco Marabotto, M., A. Cabudivo Moena and M. P. Socorro C. De CunHa (1991): Poder calorífico y pirólisis de cinco especies forestales. In: Alternativas energéticas de veinticinco especies forestales de la amazonía peruana-brasileña. Serie Sécnica $\mathrm{N}^{\circ}$ 2, pp. 25-27. Red de Información Forestal, Lima, Perú.

Toledo, E. and C. RINCóN (1996): Utilización industrial de nuevas especies forestales en el Perú. Camara Nacional Forestal, Instituto Nacional de Recursos Naturales, Organización Internacional de las Maderas Tropicales, Lima, Perú. 240 p.

UCEDA, M. (1984): Determinación del poder calorífico de 20 especies forestales de la amazonía peruana. Revista Forestal Perú 12: 98-112.

Wiemann, M. C. and G. B. Williamson (2002): Geographic variation in wood specific gravity: effects of latitude, temperature, and precipitation. Wood and Fiber Science 34: 96-107.

WiNER, B. J. (1971): Statistical Principles in Experimental Design, $2^{\text {nd }}$ Edition. McGraw-Hill Book Company, New York, USA. 906 p.

WoodCock, D. W. (2000): Wood specific gravity of trees and forest types in the southern Peruvian amazon. Acta Amazônica 30: 589-599.

Woodcock, D. W., G. Dos Santos and C. Reynel (2000): Wood characteristics of Amazon forest types. IAWA Journal 21: 277-292.

ZANGERL, A. R. and F. A. BAZZAZ (1992): Theory and pattern in plant defense allocation. In: FRITZ, R. S. and Simms, E. L. (Eds.): Plant Resistance to Herbivores and Pathogens - Ecology, Evolution, and Genetics. University of Chicago Press, Chicago, USA. pp. 363-391.

Zobel, B. J. and J. P. VAN BuIJTENEN (1989): Wood Variation - Its Causes and Control. Springer-Verlag, New York, USA.

ZobeL, B. J. and J. B. JeTt (1995): Genetics of Wood Production. Springer-Verlag, New York, USA. 